\title{
Przekład literatury dla dzieci i młodzieży - między tekstem a oczekiwaniami wydawcy i czytelnika
}

Elżbieta Zarych

TEKSTY DRUGIE 2016, NR 1, S. 206-227

DOI: 10.18318/td.2016.1.13

iteratura dotycząca przekładu utworów dla dzieci, tzw. children's literature translation studies ${ }^{1}$ jest bardzo obszerna. Teoretycy literatury i praktykujący tłumacze w swoich rozprawach analizują mechanizmy językowe i kulturowe przekładów z różnych języków, ich recepcję, porównują wersje, a także opisują własne doświadczenia. Wiele z tych prac generalnie dotyczy doświadczeń indywidualnych, zjawisk i przykładów charakterystycznych dla danego tekstu lub też po prostu wykazania wyższości przekładu własnego nad dawnymi, mniej jest opracowań ujmujących zagadnienie bardziej ogólnie, dla danego autora, języka, gatunku, dyscypliny itd. Chciałam zaproponować jeszcze jedno spojrzenie na kilka zagadnień tekstowych i pozatekstowych, związanych z przekładem literatury dla dzieci i młodzieży, spojrzenie zarówno

1 Zob. rozważania M. Borodo Children's Literature Translation Studies? - zarys badań nad literaturą dziecięcq w przekładzie, "Przekładaniec” 2006 nr 16, s. 13-14.
Elżbieta Zarych - dr, komparatystka, polonistka, redaktorka, tłumaczka literatury niemieckiej i włoskiej, recenzentka. Prowadzi zajęcia na UJ. Autorka prac poświęconych literaturze polskiej i porównawczej XIX i XX W., a także leksykonów i słowników. Ostatnio opublikowała książki Romantycy, myśliciele, inspiratorzy (2010) i Karol I Habsburg. Chrześcijański cesarz końca monarchii (2015). 
z perspektywy literaturoznawczyni, jak i tłumaczki oraz redaktorki tego typu książek.

\section{Proces wydawniczy - pomijane ogniwo decyzyjne}

Rozważania o przekładzie literackim należałoby rozpocząć od stwierdzenia, że kontakt tłumacz - tekst, relacja języków i światów to niezaprzeczalnie podstawa powstania przekładu, ale do tekstu w wydaniu książkowym, z jakim obcuje czytelnik i jaki jest przedmiotem krytyki przekładu, droga jeszcze daleka. Na drodze tej zaś pojawia się wiele czynników i osób kształtujących ostateczną wersję tekstu. Należy uwzględnić tu mechanizm instytucji (wydawnictwo i proces wydawniczy), ludzki (redaktor, korektor, składacz), a także różnego rodzaju zjawiska związane z wpisaniem danego utworu w kontekst twórczości autora, w ramy serii, a także gatunku i przeznaczenia oraz określonego odbiorcy. Dlatego każdy praktykujący tłumacz i redaktor wie, że istnieje różnica między przekładem dostarczonym do wydawnictwa, a końcową publikacją. Nie należy bowiem zapominać, że każdy tłumacz ma wpisane w umowę punkty mówiące, że wydawca ma prawo dokonywania w przekładzie koniecznych zmian i poprawek (standardowo do $30 \%$ tekstu), on też decyduje o ostatecznym kształcie dzieła (zwłaszcza w przypadku nagannego procederu braku korekty autorskiej i autoryzacji tekstu przez tłumacza), a nierzadko nawet o jego tytule 2 . Są też wydawnictwa stosujące procedurę kolacjonowania przełożonego tekstu przez drugiego tłumacza czy po prostu osobę znająca język i nietrudno się domyślić, że taka osoba nigdy nie zgadza się ze sczytywaną wersją tekstu, a efekt tych poprawek podpisany jest nazwiskiem tłumacza mającego umowę na przekład. Kwestie merytoryczne i językowe bywają więc często traktowane przez wydawcę tak samo, jak wybór czcionki, formatu czy strategii promocyjnej. Z drugiej zaś strony bywa, że tłumacz jest niepewny swojej wersji i zwraca się do redaktora o pomoc w rozstrzygnięciu wątpliwości lub też nawet niekiedy zostawia po ukośnikach formy czy zwroty do wyboru. I nie jest też tak, że ten pierwszy powstały w zaciszu domowym przekład jest lepszy czy gorszy od jego wersji końcowej, gdyż

2 Często decydują o nim cele marketingowe czy układ graficzny. Jako przykład mogę podać tu decyzję wydawcy o zmianie w przekładzie tytułu zbioru 365 fiabe, storie $i$ filastrocche (365 bajek, historyjek i rymowanek), który wiernie oddawał jego zawartość, na krótszy i chwytliwy 365 dobranocek, co wprowadziło w błąd czytelników i powodowało negatywną ocenę książki jako pozycji nienadającej się na dobranoc. Zmiana tytułu spowodowała narzucenie książce wymagań sprzecznych z pierwotnym założeniem. 
wszystkie te czynniki i osoby na drodze między oryginałem a opublikowanym przekładem mogą oddziaływać zarówno pozytywnie, jak i negatywnie. Najczęściej proces wydawniczy oraz jego mechanizmy i pracujący przy nim ludzie ingerują w tekst w sposób złożony: zarówno na korzyść, jak i na niekorzyść tekstu, a jego narodziny w wersji końcowej są zawsze efektem współpracy, walki, dyskusji, negocjacji i kompromisów.

Najkorzystniejsza dla tekstu jest oczywiście sytuacja, gdy wszelkie zmiany w nim są konsultowane i dyskutowane, a tłumacz, redaktor i wszyscy pracownicy wydawnictwa są kompetentni i spostrzegawczy, na przekład i tłumaczenie przeznaczono odpowiednią ilość czasu i nie zdarzają się żadne wypadki losowe. Jednak i to pozostaje w sferze teorii i pobożnych życzeń, a życie niesie z sobą błędy, przeoczenia, napięte terminy i mnóstwo różnych wypadków. Z wieloletniego doświadczenia tłumaczki i redaktorki literatury, w tym tekstów tłumaczonych, mogę powiedzieć, że przekład końcowy jest wypadkową wszystkich tych czynników, podobnie jak każdy wytwór rąk ludzkich, najlepszym, jaki udało się wypracować tu i teraz, ale który przecież zawsze mógłby być lepszy, jeśli nie teraz, to z perspektywy czasu i nowych doświadczeń. I każdy tłumacz też przyzna, że sam, czytając po latach własny przekład, zawsze znajduje miejsca, co do których obecnie podjąłby inne decyzje i w których wprowadziłby zmiany ${ }^{3}$. Nie ma przekładu obiektywnie idealnego - tym bardziej że żąda się od niego, żeby godził sprzeczności: z jednej strony był ponadczasowy, a z drugiej przestrzegał aktualnych kanonów ${ }^{4}$ - tak jak nie ma jedynie słusznych odpowiedzi na wiele związanych z przekładem pytań, m.in. czy i kiedy należy trzymać się wiernie tekstu, która wersja jest lepsza itd. Każda książka i przekład wymaga bowiem indywidualnego podejścia.

Tylko kiedy traktujemy przekład jak rzemiosło, możemy zamknąć się w kategorii sformułowanej przez prawników jako „stworzenie dzieła wykonanego pod względem fachowym, merytorycznym i językowym na poziomie, jakiego można wymagać od twórców zajmujących się zawodowo tworzeniem dzieł tego rodzaju”. Zwrot „sztuka przekładu” jednak zobowiązuje i tak jak w każdej

3 Zob. np. uwagi B. Sochańskiej Czy potrzebny był nowy przekład baśni Andersena?, „Przekładaniec" $2009 \mathrm{nr}$ 2-2010 $\mathrm{nr}$ 1, $\mathrm{nr}$ 22-23, s. 111.

4 J. Święch Przekład a problemy poetyki historycznej, w: Problemy metodologiczne współczesnego literaturoznawstwa, red. H. Markiewicz, J. Sławiński, Wydawnictwo Literackie, Kraków 1976, s. 370; M. Adamczyk-Garbowska Polskie tłumaczenia angielskiej literatury dziecięcej. Problemy krytyki przekładu, Ossolineum, Wrocław 1988, s. 11-12.

5 Standardowy zwrot używany w umowach wydawniczych zawieranych z tłumaczem. 
sztuce, także tutaj wiele jest kwestii subiektywnych zarówno decydujących o powstaniu utworu, jak i jego ocenie. Na powstanie opublikowanego przekładu wpływ ma też wiele innych czynników, m.in. socjolingwistycznych i socjologicznych ${ }^{6}$, emocjonalnych, pozamerytorycznych, związanych z autorem i odbiorca, a nawet z typem wydawnictwa. W żadnej innej literaturze nie jest to tak widoczne, jak właśnie w literaturze dla dzieci i młodzieży. Chciałabym przedstawić najważniejsze zjawiska występujące w relacji między tekstem, tłumaczem, wydawcą i czytelnikiem ${ }^{7}$, każdy z tych elementów, choć przypisujemy przekład jedynie osobie wymienionej na stronie tytułowej, w znaczący sposób wpływa na ostateczny kształt książki.

\section{To tylko książka dla dzieci...}

Kiedy myślimy o przekładzie literackim, tłumaczenie literatury dla dzieci i młodzieży wydaje się czytelnikom, wydawcom i początkującym tłumaczom o wiele prostsze od tłumaczenia „poważnej literatury”. Język jest prostszy, brak skomplikowanych nazw i odwołań, historia też wydaje się lekka, łatwa i przyjemna. W utworach tych często czai się jednak wiele pułapek, z których istnienia, nie zagłębiając się w to zagadnienie, nie zdajemy sobie sprawy lub też o których, obcując z gotowym przekładem, po prostu nie myślimy. Oczywiście i tutaj, tak jak w każdym tłumaczeniu literackim, istnieją różne problemy i pytania związane ze zjawiskiem przekładu, w rozwiązaniu których i odpowiedzi na które zaznacza się wpływ różnych tendencji translatorskich, jednak przekład literatury dla dzieci i młodzieży jest specyficzny zarówno ze względu na czynniki tekstowe, jak i przede wszystkim pozatekstowe.

Na poziomie tekstu tylko w utworach dla dzieci, których warstwa fabularna w większym stopniu opiera się na wyobraźni i grach słownych, może się zdarzyć, że konstrukcja tekstu ma za podstawę grę słowną, powiedzenie, związek frazeologiczny, przysłowie, żart. Sposób poradzenia sobie z tym wyzwaniem decyduje o jakości całej historii, jej komizmie, zagadkowości itd. Może też się zdarzyć, że takiej książeczki nie da się po prostu przełożyć na język obcy, bo w odpowiedniku tego powiedzenia czy przysłowia występują

6 Por. J. Pieńkos Przekład i tłumacz we współczesnym świecie. Aspekty lingwistyczne i pozalingwistyczne, PWN, Warszawa 1993, s. 40 i n.

7 Oczywiście jak w każdym wypadku, tak i tu zdarzają się wyjątki, które najczęściej potwierdzają regułę. Nawet przy książkach na trudne tematy odważni wydawcy czy tłumacze stają przed dylematem odbioru. 
np. inne postacie. Jeszcze trudniej jest, jeśli historii towarzyszą obrazki. Jako przykład podam tu niemiecką bajeczkę o krowach, które według niemieckiego przysłowia w nocy wszystkie są czarne (w polskiej to koty). Przekład byłby niemożliwy lub bardzo trudny i dodatkowo wymagałby całkowitej lub częściowej rezygnacji z ilustracji. Oczywiście takie sytuacje zdarzają się i w literaturze dla dorosłego czytelnika, ale nie na taką skalę i nie stanowią o całości fabuły.

Także bardziej niż w przypadku każdej innej literatury prawdziwe jest stwierdzenie, że przekład utworu polega na jego opowiedzeniu w swoim języku. Przełożenie lub wręcz wymyślenie imion i nazw dla baśniowych i fantastycznych postaci, użycie wyobraźni, by jak najlepiej oddać ducha opowieści, i podjęcie rozsądnych decyzji ${ }^{8}$, co jest istotne dla opowiedzianej historii, a co można lub należy zmienić, to decyzje często dyktowane zarówno tekstem, jak i czynnikami pozatekstowymi. Nawiązując do klasycznego już podziału Wernera Kollera, tu przekład może być zarówno transferem, jak i adaptacją choć w drugim przypadku nieustannie powracają pytania teoretyków, krytyków i samych tłumaczy, kiedy i jaką. Tylko w literaturze dla małych dzieci konieczne staje się niekiedy wymyślenie historii, opowiedzenie jej w swoim języku i kodzie kulturowym, zwłaszcza gdy jest to krótka historia czy wierszyk, którego cel jest inny niż zarysowanie świata odmiennej kultury. I tak np. w wierszyku Zima (L’inverno) ta pora roku pachnie „futrami z szafy, / gorącą kawą, / makowcami / i świątecznymi prezentami, / choinką oraz śniegiem i Bożym Narodzeniem"10. Zachowanie oryginalnych włoskich propozycji zapachu baru, cappuccino, panettone, frittelli itd. w kilkuwersowej rymowance raczej wprowadziłoby w błąd i wymagałoby komentarzy obszerniejszych niż sam wierszyk. Zastąpienie typowych dla Wenecji frittelli polskimi pączkami też nie było dobre, bo kojarzą się u nas z karnawałem i tłustym czwartkiem, a nie z Bożym Narodzeniem. Tłumacz musi być też pierwszym interpretatorem, który - jak twierdzi wielu teoretyków - musi dokonać egzegezy,

8 Nawiązując do tytułu książki P. Kußmaula Übersetzen als Entscheidungsprozeß, w: Übersetzungswissenschaft. Eine Neuorientierung, wyd. 2, Francke,Tübingen-Basel 1994, oraz artykułu J. Levý'ego Przekład jako proces podejmowania decyzji, „Pamiętnik Literacki” 1981 LXXII, z. 1 przekład to (różnie rozumiany) proces podejmowania decyzji.

Por. W. Koller Einführung in die Übersetzungswissenschaft, wyd. 4, Quelle und Meyer, Heildelberg-Wiesbaden 1992; M. Krzysztofiak Przekład literacki we współczesnej translatoryce, Wydawnictwo Naukowe UAM, Poznań 1996, s. 32. 
a dodatkowo uświadomić sobie obcość przekładanego tekstu w stosunku do własnego języka i kultury"1. W omawianym przykładzie wierny przekład mijał się z celem rymowanki: opowiedzenia małym dzieciom o nastroju zimy; luźne podejście ułatwił tu brak wiernie odnoszących się do treści ilustracji. Tylko w literaturze dla dzieci tłumacz musi się bowiem liczyć z towarzyszącymi książce ilustracjami. Najtrudniejsza jest sytuacja, gdy osoby czy rzeczy zostały zestawione ze sobą w tekście i na ilustracji ze względu na rym między nimi, idiom czy nazwę, istniejące jedynie w języku oryginału, ale już nie w przekładzie. Jako przykład podam tu skojarzenie głównej bohaterki książki Luigiego Balleriniego La Signorina Euforbia na słowo frusta, które oznacza zarówno trzepaczkę do ubijania piany (o którą chodziło), jak i bicz - stąd ilustrujący je obrazek przedstawiający poskramianie lwa ${ }^{12}$. W przekładzie nie tylko należałoby zmienić skojarzenie, ale i rysunek. Ale bywa też, że ilustracje są podpowiedzią dla tłumacza. W popularnej serii Daniela Nappa o misiu Brummie jednym $\mathrm{z}$ bohaterów jest rolnik Hackenpiep, która to nazwa jest złożeniem słów „kopać/rąbać” i „piszczeć”. Początkowe pomysły słowotwórcze Ryjopisk czy Kopalski skończyły się studiowaniem ilustracji i dyskusjami, jakie to zwierzę (ryjówka, wydra, łasica?) ${ }^{13}$. Z powodu niejasności ilustracji rolnik został po prostu Ryjkiem. Także żaden z tłumaczy tej serii na inne języki nie zdecydował się na stworzenie neologizmu, ale wybrał podobne rozwiązania - np. w wersjach szwedzkiej i duńskiej został Bobrem, a w angielskiej otrzymał imię Giles.

Podobnie miś z tej samej serii nie został jak w oryginale doktorem ${ }^{14}$, bo w Polsce każdemu dziecku kojarzyłoby się to przede wszystkim z zawodem lekarza, gdy w Niemczech ten tytuł naukowy jest tak popularny, że niemal równoznaczny z naszym „pan”. Podobną decyzję podjęli tłumacze tej serii na duński (Hr. Brum), szwedzki (Herr Brum), niderlandzki (Meneer Brom), a po fińsku został nazwany Mikko Murina, czyli Miś (także Michał) Mruczący. Widać więc, że tłumaczenie to nie tylko oddanie w swoim języku tekstu, ale

11 Zob. opinie teoretyków w M. Krzysztofiak Przekład literacki, s. 44 i n.

12 L. Ballerini La Signorina Euforbia, San Paolo, Milano 2014, s. 46.

13 Zwierzę to przypomina wydrę, którą w części Pan Brumm idzie się kąpać autor nazwał Panem Wydrą, więc być może albo się w dalszych częściach pomylił, albo zmienił zdanie. Pomyłki i niekonsekwencje autora, z którymi musi się zmierzyć tłumacz, to osobna kwestia.

14 Jak pisze na swojej stronie autor, tytuł ten przegłosowały dzieci, przyznając mu go w dziedzinie "jedzenia miodu". Zob. http://www.daniel-napp.de/dr-brumm.html 28.03.2014 (15.03.2014). W książkach nie ma jednak na ten temat ani słowa. 
i jego sensu. Może ono odbiegać często dość daleko od wzorca, tak że trudno jest nawet domyślić się, jaką formę przybrało w kolejnej wersji językowej; tu np. w rosyjskiej.

Rozumienie sensów zakodowanych w słowach, interpretacja dzieła dla celów przekładu i kreatywność $\mathrm{w}$ tym procesie $\mathrm{e}^{15} \mathrm{w}$ przypadku literatury dla dzieci, zarówno w prozie, jak i w poezji, są jeszcze bardziej istotne. Także częściej w praktyce spotyka się nie tylko z ekwiwalencją, ale i z koherencją ${ }^{16}$, a więc odpowiadaniem przekładu oczekiwaniom, potrzebom i zainteresowaniom odbiorców wykształconych w kulturze języka przekładu. $\mathrm{Na}$ tym poziomie w niektórych przypadkach historii dziejących się wszędzie i nigdzie lub w baśniowej krainie niezbędne staje się działanie sprawiające, że obcość, będąca jednym z nieodłącznych czynników przekładu (tzw. strategia wyobcowania) ${ }^{\mathbf{1 7}}$, zostanie częściowo zatarta lub całkowicie wyeliminowana i nic poza nazwiskiem autora i informacją o przekładzie nie będzie przeszkadzało młodemu czytelnikowi w odbiorze. Oczywiście inaczej będzie w przypadku książek, w których prawdziwy kraj i rzeczywista kultura kreują świat opowieści, a obcość jest jedną z integralnych wartości dzieła. Charakter utworu, jego struktura i cel, a także odbiorca decydują o podjętych przez tłumacza wyborach i koncepcji przekładu. Gdyby np. powyższy wiersz o zimie był przeznaczony dla dorosłego czytelnika, zapewne zostałby przełożony inaczej, z zachowaniem obcości i wielu włoskich detali, być może też pojawiłyby się przy nim przypisy. O przekładzie literatury dla dzieci i młodzieży zawsze decydują jednak zarówno czynniki tekstowe, jak i pozatekstowe, a jak silne są te drugie, można się przekonać, choćby próbując znaleźć odpowiednią nazwę (i tytuł książki Daniela Nappa) dla świnki o imieniu Supadupa ${ }^{18}$.

\section{Dla dzieci, ale których? - między dzieckiem a dorosłym}

Tłumacze literatury dla dzieci i pedagodzy zwracają uwagę na osobne traktowanie literatury dla dzieci i młodzieży, obojętnie, czy oryginalnej, czy

15 Por. cechy przekładu literackiego w M. Krzysztofiak Przekład literacki, s. 37-57.

Określenie zob. P. Kußmaul Übersetzen als Entscheidungsprozeß, s. 206-229.

I. Pascua Translation and Intercultural Education, „Meta” 2003/48. Zob. też M. Borodo Children's Literature, s. 20-21.

Kojarzący się z wulgaryzmem tytuł opiera się na ang. przymiotniku oznaczającym w miejskim slangu "niezły, świetny". 
tłumaczonej, ze względu na młodego odbiorcę i przypisywane mu cechy. I oczywiście, jak pisała Riitta Oittinen, ma się tu na uwadze nie konkretnego odbiorcę, ale abstrakcyjnego superadresata ${ }^{19}$. Skandynawscy teoretycy jak Oittinen, Göte Klingberg, Birgit Stolt czy Tiina Puurtinen podkreślają, że sposób przekładu zależy od tego, dla jakiego dziecka się przekłada, oraz, że tłumacz powinien „dotrzeć do obrazu dziecka wytworzonego w ramach swojej kultury" i ponownie doświadczyć dziecka w so$b e^{20}$. Należałoby dodać, że nie tylko w kulturze, ale i w czasach, w których żyje, a także, że obraz dziecka może być niekiedy różny, w zależności od tego, kto go wytwarza i na jego podstawie weryfikuje jakość danego dzieła.

Nawiązując do wyobrażonego obrazu dziecka i sięgania do swego dzieciństwa, należałoby odróżnić obraz dziecka, dla którego pisze autor, od obrazu wytworzonego przez tłumacza oraz widzianego oczyma wydawcy i potencjalnego czy konkretnego rodzica. Oczywiście w całym tym łańcuchu decyzyjnym nie pojawia się głos dziecka, bo jak słusznie zauważyła Karolina Albińska, opierając się na poglądach zachodnich badaczy, proces decyzyjny na wszystkich etapach zależy od dorosłych, którzy starają się „sprawować kontrolę nad książką jak nad swoimi dziećmi"21. I nie zawsze mogą zrozumieć to, że literatura rządzi się swoimi prawami i nie są to prawa hierarchii i władzy. Zakładając, że autor tworzy dla określonego obrazu dziecka (nieważne, czy konkretnego, abstrakcyjnego czy tego w sobie), a książka ta w przekładzie trafia do dziecka w innym kraju, tłumacz znajduje się w sytuacji wyboru dostosowania się do obrazu dziecka oryginału, a obrazu odbiorcy, który sam posiada (lub dziecka w sobie), lub też dodatkowo, jaki stawiają mu za wzór wydawcy i rodzice. I znów każdy wybór niesie z sobą inne ryzyko, prowadząc do obcości, niezrozumiałości, przeróbek, adaptacji czy wygładzeń.

Ciekawe jest to, że wydawcy i rodzice są w stanie wybaczyć tłumaczeniu wiele, jeśli chodzi o kwestie wierności, ale nie wybaczają i nie przyjmują takich, w których naruszane jest ich zdaniem „dobro dziecka”. Bo

19 R. Oittinen I am Me - I am the Other: On the Dialogics of Translating for Children, University of Tampere, Tampere 1993, s. 68.

20 Zob. omówienie opinii przez K. Albińską "Tylko to, co najlepsze, jest dość dobre dla dzieci”, czyli o dylematach tłumacza literatury dziecięcej, "Przekładaniec” 2009 nr 2-2010 nr 1, nr 22-23, s. $259-260$.

21 Zob. tamże oraz P. Hunt Children's Literature, Blackwell, Oxford-Malden 2001, s. 225. 
w naszej kulturze dziecku trzeba dać wszystko co najlepsze, a jak dodaje Albińska, nawet to, co najlepsze, nie jest czasem dla niego dość dobre. Przed omówieniem, na czym polega owo dobro i jakie cechy ma dziecko, o które dbają polscy wydawcy i rodzice, warto zwrócić uwagę na wybór książek do publikacji w przekładzie na polskim rynku. Można wyróżnić cztery grupy książek wybieranych ze względu na różne motywacje:

1) klasyka literatury, czyli lektury szkolne oraz książki osadzone w tradycji, czyli takie, które każde dziecko znać powinno (na których wychowywali się decyzyjni dorośli);

2) książki nowatorskie wybierane ze względu na treść czy ilustracje (często o wyborze decydują też otrzymane nagrody);

3) książki popularne, odpowiadające przeciętnemu odbiorcy, lub takie, którym towarzyszą filmy, gry, maskotki itp. (tzw. „produkt totalny”);

4) książki „przyjazne dziecku” (wybór np. ze względu na walor edukacyjny, estetyczny).

We wszystkich tych grupach zdarza się jednak, że najpierw wybiera się książkę ze względu na jakieś walory oryginału, a potem stara się ją dostosować do abstrakcyjnego polskiego dziecka. Przyjrzyjmy się raz jeszcze powodom wyboru: na czoło wysuwają się sentymentalne, estetyczne, dydaktyczne, edukacyjne, finansowe, dalej bezpieczeństwo dziecka i wyobraźnia. Wybór książek przez wydawcę jest więc wyborem dokonywanym przez dziwną mieszankę „dziecka” i „dorosłego", z jednej strony realizującego marzenia i pragnienia „dziecka w sobie", a z drugiej wykonującego pracę zarobkową i nastawionego na zysk.

Mieszankę „dziecko-dorosły” widać też w decydującym o zakupie książek rodzicu, także poszukującym czegoś dla dziecka w sobie (nie bez powodu najbardziej popularne na rynku są książki lubiane w czasach dzieciństwa przez pokolenie aktualnie posiadające dzieci), a czegoś odpowiedniego dla własnego potomka. Maria Kielar-Turska, przeprowadzając w latach 9o. badania na temat motywów czytania baśni w opiniach dorosłych i dzieci, zauważyła, że dorośli wybierali je przede wszystkim ze względu na walor dydaktyczny (aż 51,2\%; zaś aż dla 79,5\% był to powód polecania ich innym rodzicom), następnie poznawczy $(13,3 \%)$, po tyle samo emocjonalny i rozwojowy $(11,1 \%)$ oraz instrumentalny $(6,7 \%)$. Tymczasem dzieci kierowały się przede wszystkim walorem poznawczym (30,6\%), estetycznym (25,4\%) i emocjonalnym $(20,3 \%)$. Widoczne jest więc, że motywy rodziców i dzieci są zupełnie odmienne: dorośli, przyjmując rolę rodzica i wychowawcy, szukali tego, co uczy 
zasad, zawiera morał, kształci i pokazuje, a dopiero potem rozwija wyobraźnię i emocje, dzieci zaś wybierały to co ciekawe, ładne i wzruszające czy zabawne ${ }^{22}$. I niewiele się tu na przestrzeni lat zmieniło, co można prześledzić, analizując wypowiedzi na portalach dyskusyjnych rodziców wybierających książki dla własnych dzieci. I co ciekawe: na innych stronach rodzice wspominający swoje ulubione książki czy bajki animowane swojego dzieciństwa opowiadają o nich i oceniają je w sposób identyczny jak dzieci, tj. w ogóle nie zwracając uwagi na walory dydaktyczne, czyli na to, co decyduje często o pozytywnej ocenie książki dla własnego dziecka, ale patrzą z emocjonalnej perspektywy kilkulatka.

Kwestia ta jest niezwykle istotna w uzależnionym od tak wielu czynników subiektywnych typie przekładu. Książki napisane w języku ojczystym są dobre lub złe, właściwe lub niewłaściwe, ich ocena i wybór (przez wydawcę i rodzica) są prostsze, książek tłumaczonych zaś bardziej złożona. Wśród kupowanych licencji na uznane za dobre i wartościowe książki zagraniczne można wyróżnić dwie problematyczne grupy:

1) klasykę literatury; poznaną w określonej wersji, która rzutuje na ocenę kolejnych przekładów;

2) książki wysoko cenione za granicą; w szczegółach często okazuje się jednak, że coś jest nieodpowiednie dla polskiego dziecka i ma to dostosować właśnie tłumacz.

Jak widać tłumacz literatury dziecięcej staje między tekstem i autorskim dziecięcym odbiorcą a mieszanką dorosłego i dziecka w wydawcy (będącego też pierwszym czytelnikiem) i w rodzicu. A na dodatek on sam też ma często jakieś wyobrażenie dziecka, dla jakiego tłumaczy, i owo wspomniane już przez badaczy „dziecko w sobie”. Jeśli spojrzymy na ten proces z tej perspektywy, widoczne staje się, dlaczego tłumaczenie literatury dla dzieci i młodzieży jest trudniejsze od każdego innego. W obrębie każdej z osób decyzyjnych (w różny sposób) w procesie powstania i publikacji przekładu zachodzi konflikt "dorosłego" i „dziecka” w nim samym, a na dodatek w tej i tak sporej "gromadce" pracującej nad książką dla młodego odbiorcy należy widzieć z jednej strony obudzone dzieci, a z drugiej odpowiedzialnych dorosłych. A wszystkie te "dzieci” i „dorośli” czasem nie mogą się ze sobą porozumieć. Stąd też nigdy nie powstaje wersja, która odpowiadałaby wszystkim, i każda w jakimś aspekcie jest krytykowana. Nie ma wersji, której inny tłumacz, krytyk, rodzic

22 M. Kielar-Turska Odkrywane wartości baśni, w: Dziecko jako odbiorca literatury, red. M. Kielar-Turska, M. Przetacznikowa-Gierowska, PWN, Warszawa-Poznań 1992, s. 142-143. 
itd. czegoś by nie zarzucił. Wyjątkiem są dzieci, dla których wszystko to jest o wiele prostsze, bo patrząc z dziecięcej perspektywy, najczęściej po prostu odróżniają opowieści ciekawe, niesamowite, zabawne, wesołe od nudnych, schematycznych, smutnych itd.

\section{Przekład niby nowy a stary}

Sporą grupę książek przekładanych stanowi klasyka literatury. Wiele wydawnictw wznawia stare przekłady, kierując się zarówno względami formalnymi (mniejszymi kosztami, krótszym czasem procesu wydawniczego itd.), jak i tradycją. Popularne książki, zwłaszcza dla dzieci i młodzieży, często istnieją bowiem w pamięci i w sercach dorosłych i młodych czytelników w określonych wersjach i nawet jeśli są one przestarzałe pod względem językowym czy w różnych kwestiach dalekie od oryginału, to dla wielu z nich inna wersja jest po prostu niewyobrażalna, a niekiedy wręcz niemal graniczy ze świętokradztwem. Działa tu zasada psychologiczna: poznane w dzieciństwie i młodości obdarzane jest sentymentem, stare i nasze, niezależnie jaką ma wartość, jest zawsze najpiękniejsze i najlepsze.

Wielu wydawców ze względu na konieczność posiadania własnego przekładu (niemożność nabycia praw na popularne) lub też zgodnie z zasadą „każdy czas ma swoją wersję" podejmuje próbę przełożenia na nowo klasyków literatury dziecięcej lub, jak nazywa je wiele oficyn wydawniczych czy portali, „książek naszego dzieciństwa” czy „książek naszej młodości”. Jednak tłumacz prędzej czy później podczas pracy znajduje się między kowadłem tekstu, a młotem tradycji i oczekiwań. Stąd, powracając do początku tego wywodu, przekład, który zostałby w szufladzie, zapewne byłby wierny oryginałowi i „intencjom autora”, a nawet odważny i obrazoburczy. Tymczasem mając świadomość oczekiwań czytelnika, niejeden tłumacz zawaha się przed wyłamującą się z tradycji zmianą. A jeśli nie, to zrobi to wydawca, sam będący z jednej strony pierwszym czytelnikiem nowego przekładu, a z drugiej buforem między tłumaczem i czytelnikami. Kilka przykładów takich problemów z tradycją i powszechnością występowania.

Andersenowska Tommelise została w pierwszym polskim przekładzie H.L. Lewestama nazwana Calinką (1859), w czym tłumacz odwołał się do znaczenia duńskiego wyrazu tomme - cal, w późniejszych Calóweczką, ale też Paluszką, Malutką, Dziecięciem elfów, by w 1909 roku w przekładzie Rygla zostać Calineczką, co powtórzyła w 1931 roku Stefania Beylin, i tak postać 
ta zapisała się w świadomości polskich czytelników. Nie zmieniły tego kolejne propozycje, jak Kruszynka, Palusia czy Odrobinka, i w kolejnych królowała już Calineczka a żaden ze współczesnych tłumaczy nie odważyłby się chyba zmierzyć z tradycją i zaproponować nowej nazwy; tak też np. zdecydowała Bogusława Sochańska w najnowszym przekładzie z 2006 roku $^{23}$. Formę tę upowszechniły też filmy. Spójrzmy na inny, także upowszechniony tytuł baśni Andersena: Mała syrenka. Sochańska myślała początkowo o bliższym jej zdaniem oryginałowi tytule Mała syrena (Den Lille Havfrue), sugerując się tym, że w duńskim zdrabnia się rzeczowniki przez dodanie „mały” - ale wówczas powstałaby w języku polskim kalka językowa - lub też jak najbardziej poprawna Syrenka. Tłumaczka, unikając skojarzeń z samochodem, wybrała jednak upowszechnioną formę Mała syrenka ${ }^{24}$, będącą z jednej strony kalką duńskiej konstrukcji, a z drugiej niepoprawną w języku polskim tautologią. Jak widać, powszechność i przyzwyczajenie są często najsilniejszym argumentem decydującym o wyborze, głównie dotyczącym nazw i imion, nawet jeśli nie zgadza się z nimi tłumacz czy one nie zgadzają się z normami językowymi. Dodatkowym problemem są prawa autorskie do popularnej nazwy, co zmusza wydawców do szukania nowych, z góry skazanych na negatywną ocenę w porównaniu do tradycyjnej (jak choćby w późniejszych propozycjach dla Kubusia Puchatka).

Niekiedy przekład będący właściwie adaptacją - co pokazuje, jak wielkie znaczenie ma będący twórcą i indywidualnością tłumacz - tak się upowszechnia, że znajomość oryginału właściwie wydaje się „szkodzić", a wierny powrót do niego po udanej adaptacji wydaje się niemożliwy. Tak jest choćby w najbardziej znanym i pierwszym przekładzie Ani z Zielonego Wzgórza Rozalii Bernsteinowej (1911), która upowszechniła malowniczą nazwę dla Green Gables ${ }^{25}$. Nie sądzę też, by jakiś tłumacz zdobył się na zachowanie oryginalnych imion pasujących do oryginalnych nazwisk i na powrót od Ani do Anne. Nawet Paweł Beręsewicz, który w swoim przekładzie (2012) wprowadził też imiona oryginalne, jak np. Mary Alice czy Shirley, pozostał przy Ani i Maryli. Zdecydował się jednak na powrót do oryginalnego imienia pani Linde, czyli Rachel, którą Bernsteinowa

B. Sochańska Czy potrzebny byłnowy przekład baśni Andersena?, „Przekładaniec” 2009 nr 2-2010 nr 1, nr 22-23, s. 105-106.

24 Tamże, s. 121.

25 Por. propozycję P. Oczko Anna z domu o zielonym dachu. O cyklu powieściowym Lucy Maud Montgomery, "Teksty Drugie” 2013 nr 5, s. 42 in. 
ochrzciła Małgorzatą, unikając imienia Rachela kojarzącego się w owych czasach z pochodzeniem żydowskim ${ }^{26}$. Ona też w ostatnim tomie Rilla ze Złotego Brzegu zamieniła Kennetha na Krzysztofa, by imię łatwiej było wyseplenić, a pies Monday został także dwusylabowym (łatwiejszym do wołania) Wtorkiem.

I jeszcze dwa zwierzęce przykłady ilustrujące inne kwestie. W oryginale książki Carla Collodiego opowiadającej o przygodach Pinokia występuje pesce-cane nazwany w polskich przekładach wielorybem. Gdybyśmy chcieli przełożyć dosłownie włoską nazwę, należałoby go nazwać rekinem. Ten potwór ze straszliwymi zębami, postrach mórz o wielkości góry i długości kilometra, nie licząc ogona, pełen statków handlowych, mebli i istot żywych, jest jednak postacią fikcyjną, niepodobną ani do wieloryba, ani do rekina. Na ilustracji Enrica Mazzantiego do pierwszej edycji książki z 1883 roku stwór ten przypomina raczej wieloryba niż rekina, co być może zainspirowało też przedstawienie potwora na słynnym filmie Disneya z 1940 roku. Wizja Disneyowska tak oddziałała na wyobraźnię widzów na całym świecie, że czytelnikom, zwłaszcza niewłoskim, trudno wyobrazić sobie inne zwierzę. Wielu tłumaczy świadomych znaczenia słowa decydowało się wybrać jednak określenie tradycyjne i zapewne także wielu redaktorów zadecydowało ostatecznie o takim rozwiązaniu. W ostatnim wydaniu z 2011 roku Pinokio. Historia pajacyka w przekładzie Jarosława Mikołajewskiego i na rysunkach Roberta Innocentiego występuje rekin, co wielu czytelników przyjęło z zaskoczeniem, a niektórzy z niechęcią, bo zawsze był wieloryb, i jak wytłumaczyć dziecku rozbieżność, że tu rekin, a tam (np. w filmie) wieloryb. Paradoksalnie baśniowa sytuacja Pinokia i wieloryba przypomina znaną biblijną opowieść o Jonaszu i wielorybie. I tu bowiem okazuje się, że zakorzenione w umysłach wyobrażenie wieloryba jest z gruntu fałszywe. W Komentarzu historyczno-kulturowym do Biblii Hebrajskiej ${ }^{27}$ czytamy, że Jonasz został połknięty przez stworzenie, które tekst określa jako „wielką rybę"28 (wieloryb jest ssakiem!).

26 Wystarczy odwołać się tu do Cudzoziemki Kuncewiczowej, w której główna bohaterka Róża zmienia imię na Ewa. Zob. też dyskusję tłumaczy i czytelników na stronie: http://www.anneofgreengables.fora.pl/tworczosc-Imm,24/zawirowania-i-klopoty-z-tlumaczeniami,925-60. html (31.03.2014). J.H. Walton, V.H. Matthews, M.W. Havalas Komentarz historyczno-kulturowy do Biblii Hebrajskiej, przeł. Z. Kościuk, Vocatio, Warszawa 2005, s. 661. 
W biblijnym wersecie w języku hebrajskim słowo לำ morskiego, lewiatana ${ }^{29}$, wszelkie morskie stworzenia (bez sprecyzowania gatunku); w religiach starożytnych duże stworzenia morskie symbolizowały siły chaosu ujarzmione przez Stwórcę. Można więc powiedzieć, że historie Jonasza i Pinokia wpłynęły na siebie, choć nieco inaczej, niż opisują to włoscy bibliści ${ }^{30}$, zapewne pomysł Collodiego ma źródła biblijne, a na wyobrażenie i w konsekwencji nazwę morskiego potwora połykającego Pinokia oddziałały losy Jonasza. Nazwanie go wielorybem nie jest tylko kwestią jakości przekładu, ale przede wszystkim wyobrażenia żywego w głowach odbiorców dużych i małych. Choćby na XIX-wiecznej rycinie Gustave'a Doré przedstawiającej Jonasza wieloryb jest bardzo podobny do pochodzącej z tego samego roku ryciny do pierwszego wydania Pinokia. Nawet w krytycznym komentarzu autorstwa Piera Citatiego do klasycznego włoskiego wydania wzorowanego na pierwszej edycji ów pesce-cane jest nazywany po prostu balena, czyli wielory $b^{31}$. Wybór tkwiącego w powszechnych wyobrażeniach wieloryba czy też dosłownego rekina być może nie zmienia w tekście wiele, ale pokazuje mechanizmy przekładu. I to, że za pozornie niewielkim wyborem jednego wyrazu w bajce dla dzieci powinna stać ogromna wiedza, a tłumacz powinien być także świetnym literaturoznawcą.

Pozostając przy tematyce morskiej, należałoby wspomnieć też o drugim ważnym bohaterze historii pajacyka: Delfinie, nazywanym konsekwentnie signor pesce (czyli: pan ryba). On też, tak jak wieloryb, nie jest przecież rybą, ale ssakiem. Czy wobec tego należy ingerować w przekład i zamienić rybę na ssaka? Czy też zostawić rybę, jak w oryginale, a określenie opatrzyć przypisem wyjaśniającym dawną lub potoczną klasyfikację? Na to wskazywałby postulat dydaktyzmu. Lecz przecież wydawcy nie lubią przypisów w książkach dla dzieci. Sama kilkakrotnie jako tłumaczka otrzymałam umowy, w których znajdował się punkt, ,unikamy stosowania przypisów" ${ }^{32}$.W tym konkretnym,

29 Wskazywałby na to opis, ale według żydowskiej legendy, midraszu Pirke de-Rabbi Eliezer z VIII/ IX w., ryba, która połknęła Jonasza, ledwie uniknęła pożarcia przez lewiatana. Zob. Pirke de Rabbi Eliezer, przeł. G. Friedlander, Hermon Press, New York 1965, s. 70.

30 R. Beretta, E. Broli Jedenaście przykazań. Półprawdy i niedomówienia na temat Biblii, przeł. M. Brzezinka, Edycja Świętego Pawła, Częstochowa 2005. Według nich Jonasz zawdzięcza powodzenie Pinokiowi. Editori, Milano 2001, s. VI. 
nieodosobnionym przypadku, widać, że wybór konkretnego rozwiązania przez tłumacza nie jest prosty, choć nie wynika z zawiłości tekstu czy złożoności języków i nie jest decyzją jednoosobową. Niejednokrotnie w tekście oryginalnym pojawia się błąd albo opisane realia wymagają komentarza, ale często wydawca, dbając o potencjalnego młodego czytelnika, mówi: przypis w książce dla dzieci źle wygląda, dzieci nie potrzebują przypisów, to dla nich za trudne, lepiej przerobić tekst tak, żeby nie trzeba było wyjaśniać. Często decyzja ta jest wymuszana na tłumaczu. Paradoksalnie argument o dydaktycznym podejściu do młodego czytelnika tutaj nie działa, raczej przeważa przekonanie, że nie należy męczyć młodych umysłów, obciążać dodatkowymi informacjami. Lektura zaś ma być lekka, łatwa i przyjemna. Dylemat, czy wprowadzić czytelnika w błąd, że delfin jest rybą, trzymając się oryginału, czy obciążyć jego młody umysł informacją o ssaku, jak widać, także jest wyborem pozamerytorycznym.

Kolejny przykład z Tajemniczego ogrodu Frances Hodgson Burnett, który zapisał się w pamięci wielu młodych czytelników w tłumaczeniu Jadwigi Włodarkiewiczowej (1914), w języku staromodnym, ale pasującym do starego domu i zapomnianego ogrodu. Pojawia się tu wścibski ptaszek o czerwonym brzuszku (ang. robin), nazwany przez tłumaczkę gilem. Można tu zauważyć pewną konsekwencję w tworzeniu translatorskiej wizji: w oryginale jest to rudzik, który to ptak nie ma czerwonego brzuszka, tylko pierś, co tak właśnie zostało opisane przez Burnett ${ }^{33}$. Włodarkiewicz zdecydowała się na zmianę nazwy, a na dodatek opisu ptaszka, być może kierując się wiedzą dzieci kojarzących ptaka o czerwonym przodzie głównie z gilem. Ten klasyczny przekład był wznawiany około 40 razy, a inne przekłady pojawiły się dopiero w latach 9o. Redagując to klasyczne tłumaczenie, opatrywałam je przypisem informującym o tej rozbieżności. W najnowszym tłumaczeniu Pawła Beręsewicza dla Skrzata z 2011 roku robin to już rudzik (co dodatkowo zostało opatrzone przywodzącą na myśl atlasy przyrodnicze ilustracją z opisem). Tu ten drobny problem zniknął, bo współczesne dziecko powinno znać rudzika. Przekład jest napisany nie tylko dla współczesnego czytelnika, ale i pod niego, jest zawadiacki, napisany współczesnym językiem, z dodatkiem gwary, a także z komentarzem tłumacza przepraszającym czytelnika, że będzie się musiał z tym zmierzyć, ale to nie takie straszne. $Z$ jednej strony mamy więc przekonanie, że dziecko jest mądre i takiego rudzika znać powinno, z drugiej

33 Tak też w oryginale "a bird with a bright red breast". Zob. The Secret Garden, http://www.gutenberg.org/files/113/113-h/113-h.htm\#chapo4 (1.01.2016). 
zaś komentarze przepraszające za obciążenie jego młodego umysłu dodatkową wiedzą.

Po ukazaniu się książki Christiana Bienieka Karolka Karotka. Silne dziewczyny trzymają się razem (2008) na łamach „Metra” ukazała się recenzja, w której skrytykowano pozostawienie oryginalnych imion dziewczynek: Karoline, Esther, Tanja i Yildiz. Zwłaszcza to ostatnie imię wywołało oburzenie recenzenta, a w komentarzach internetowych także niektórych rodziców. Najdziwniejsze było to, że była to już ósma i ostatnia książka z serii, nikt nie zadał sobie trudu zagłębienia się w akcję i w to, że toczy się ona w Düsseldorfie, dziewczynki mają też obco brzmiące nazwiska, więc absurdalne zrobienie z nich np. Ani czy Kasi sugerowałoby, że są to polskie imigrantki z rodzin mieszanych. Tymczasem są one Niemkami, jedna z nich z rodziny niemiecko-amerykańskiej, a ostatnia to Turczynka. „Obrona” dzieci przed tym, co trudne i obce, wydaje się dziwna w czasach, gdy dzieci mają w swoich klasach czy spotykają na wakacjach osoby o jeszcze dziwniejszych imionach. Co najciekawsze, dzieciom to w ogóle nie przeszkadzało. Argument o tym, że nie wiadomo, jak poprawnie wymawiać to imię, też zastanawia, gdy z pewnością większość czytelników nie wymawia poprawnie np. Pippi Långstrump i wcale im to nie przeszkadza.

Jak wobec tego jest postrzegane współczesne dziecko? Wydaje się, że dzieci posługujące się komputerami czy innym sprzętem elektronicznym lepiej od rodziców, jeżdżące po świecie i znające wiele miejsc nie tylko z książek czy telewizji powinny być traktowane adekwatnie do swego rozwoju i współczesnego świata. Tak jednak nie jest. Przeciętny dorosły: rodzic, a często i bojący się jego reakcji wydawca, unikają poważnego potraktowania dziecka jako istoty myślącej, która też ma jakąś wiedzę i która chętnie się uczy i dowiaduje czegoś nowego. Widać to w unikaniu w języku polskim trudnych miejsc, przypisów, nazw, ale paradoksalnie ci sami obrońcy często nie mają z tym problemu, gdy posyłają dzieci na zajęcia z języków obcych.

We wszystkich tych przykładach widać też, że tłumaczenie przebiega z jednej strony jako praca fachowca, a z drugiej często odzywa się w tłumaczu lub wydawcy - tak jak w rodzicu - opiekun i obrońca dziecka przed trudnym i złym światem. Tak jak zadaje się pytanie o model dziecka, dla którego powstają książki, tak należy też spytać o obraz dziecka, jaki noszą w sobie tworzący i dbający o właściwą literaturę dla milusińskich dorośli, a także o obraz dorosłego, jaki reprezentują, i o to, jak postrzegają siebie i swoją funkcję. 


\section{Niewinność ocalona}

Rys ten jest chyba najbardziej widoczny, kiedy chodzi o obronę dziecka nie tylko przed światem pełnym obcych i trudnych nazw oraz nowych informacji, ale przed złem, okrucieństwem i przemocą, choćby w literaturze przełożonej. Sztandarowym przykładem są tu oczywiście baśnie braci Grimm, pełne makabrycznych scen. Oczywiście osobną kwestią jest pierwotne przeznaczenie tych utworów, które z czasem znalazły się w pokoju dziecięcym - w czym niebagatelną rolę odegrało potoczne rozumienie baśni jako bajki - i w wyniku dopasowywania do potencjalnego odbiorcy powstało wiele ich adaptacji i przeróbek. W przypadku tych baśni mamy do czynienia z jednej strony z postrzeganiem ich jako utworów uświęconych tradycją i które należy znać, a z drugiej takich, z którymi coś trzeba zrobić, bo w wersji oryginalnej nie nadają się dla dzieci. Klasyczna jest już wypowiedź Stefanii Wortman, redaktorki książek dla najmłodszych w wydawnictwie Nasza Księgarnia, która tak opisała swoją pracę: „Starannie wybierałyśmy i dobierały baśnie, żeby tylko nie było w nich czegoś okropnego. Nasz wybór baśni Grimmów został oparty na wydaniu niemieckim, lecz zmieniono zakończenia. Na przykład macocha Królewny Śnieżki nie tańczyła aż do śmierci w rozpalonych pantofelkach, tylko umierała krótką bezbolesną śmiercią na widok szczęśliwej pasierbicy [...]. Oczywiście nie można było w tym wyborze zamieścić Jasia i Małgosi, bo sprawa palenia czarownicy to zbyt okropne"34. Dziś oczywiście redaktorzy i tłumacze nie stosują aż tak ścisłej cenzury moralnej i emocjonalnej, jednak $\mathrm{w}$ wielu przypadkach ten problem powraca.

O tłumaczeniach baśni braci Grimm napisano wiele, ja chciałabym dodać tylko dwie uwagi. Moim zdaniem o ocenie tego, co jest właściwe dla dzieci, a co takie nie, często decyduje nie tyle okropność scen, co utrwalone schematy. Tak więc np. w Królewnie Śnieżce nie razi rodziców (a i występujących w ich interesie wydawców), że myśliwy miał przynieść królowej na dowód zabicia Śnieżki jej serce, ale już przekład zgodny z oryginałem, a więc zastąpienie serca płucami i wątrobą, w jakiś sposób rodziców zniesmacza i oburza. Podobnie wydziobanie przez gołąbki oczu siostrom Kopciuszka czy wprowadzenie innych (a zgodnych z oryginałem) zmian w stosunku do utartych rozwiązań. Wydaje się więc, że często obrońcom niewinności dziecka chodzi nie tyle o wyeliminowanie okrutnych scen, co jedynie o niewprowadzanie zmian w utrwalonych wersjach. Szokuje nie to, co okrutne i przerażające, ale

34 Cyt. Za: H. Skrobiszewska Baśń i dziecko, Ludowa Spółdzielnia Wydawnicza, Warszawa 1978, s. 228. 
to, co w jakiśs sposób nowe. Nie zastanawia, że jeszcze gorsze od wydziobania oczu jest np. pożarcie przez wilka czy spalenie żywcem w piecu. To, co znane i osadzone w tradycji, już tak nie działa na wyobraźnię. Podobnie strażników moralności oburza brzydkie słowo, ale wcale nie oburza regularne wspinanie się królewicza do wieży Roszpunki, co oczywiście zaowocowało ciążą. Rodzice myślą bowiem przede wszystkim nie o tym, co może być straszne dla dziecka, ale co przeraża ich samych jako „dzieci” i jako opiekunów³5.

Zarzuty co do tych kwestii, co ciekawe, rzadko dotyczą samego autora, gdyż to od tłumacza oczekuje się, że wyeliminuje z książki brzydkie wyrazy, gorszące sceny czy poglądy autora, które nie odpowiadają wydawcy i odbiorcy (często wydawca zasłania się tu nieadekwatnością sceny czy zdania dla polskiego rynku). Aż ciśnie się na usta pytanie, dlaczego wydaje się książki, które są tak „złe” i „nieadekwatne”, ale oczywiście odpowiedzią jest tradycja literacka lub chęć posiadania bestsellera. Tłumacz zaś ma taką książkę nie tyle przełożyć, ale dostosować ją do oczekiwań wydawcy, rynku i potencjalnego czytelnika, a właściwie jego rodziców.

\section{Ładnie, poprawnie, radośnie i z happy endem}

Tekst przeznaczony dla młodego czytelnika musi być ładny i poprawny, a dla małego dodatkowo przyjazny i radosny. Niekiedy wydawca oczekuje, że tłumacz „dosłodzi” język książki dla dziecka albo zgodzi się na takie zmiany. Równie nadgorliwy bywa w książkach dla młodzieży, gdzie próbuje uładzić język do form poprawnych i stylistycznie neutralnych lub wysokich, mimo że bohater mówi właśnie językiem młodzieżowym, ma swoje powiedzonka i sposób wyrażania się nie zawsze poprawny. Przeciętny wydawca często stara się, żeby wszystko było ładne, chociaż w oryginale tak wcale nie jest. Argument o świętości oryginału nie jest skuteczny, bo cel uświęca środki. Najtrudniej jest, jeśli książka jest jedną z serii, co do której obowiązują ustalone odgórnie wytyczne, z którymi nawet jeśli tłumacz danego utworu się nie zgadza, a dany tytuł do nich nie pasuje, nie ma od tego odwołania. Przekład może się ukazać albo w wersji rzemieślniczo dostosowanej do wytycznych, albo wcale. Podam tu przykład wytycznych z umowy odnośnie do książki w ramach jednej z serii dla młodzieży: „Uwaga: imię Franzisca występuje w oryginale również w wersji Franzi. W polskiej wersji używamy tylko formy

35 Por. np. dyskusje na forum: http://forum.gazeta.pl/forum/w,46,143210232,143222277,Re_Basn_ lektura_Il_klasa_w_ktorej_krew_sie_le.html (30.03.2014). 
Franzisca, ponieważ Franzi może się kojarzyć negatywnie ze słowem franca". Nieważne, że tłumacz uważa, że młodzież powinna poznawać także funkcjonujące w różnych krajach zdrobnienia imion czy że młodzież nie ma pojęcia co to jest franca i najpierw trzeba by jej to wytłumaczyć. Decydujące słowo ma zawsze przezorny wydawca, dowodzący też, że poprzedni tłumacze pozycji w serii przecież się na to zgodzili.

Od tłumaczy oczekuje się także, że jakoś złagodzą smutne fragmenty (a w dawnej praktyce zdarzało się, że nawet zmienią zakończenie), żeby było pogodne, a utwór nadawał się do czytania nawet przed snem. Bagatelizuje się tu potrzebę zapoznania się przez dzieci w złagodzonej formie z różnymi aspektami życia, a także tego, że dziecko w pewnym wieku ekscytuje się strasznymi historiami czy groźnymi zwierzętami. Przytoczę tu rozmowę na jednym ze spotkań autorskich, na których jedna z mam delikatnie sugerowała, że niektóre historie są trochę smutne, a jej córka (ok. 5-letnia) zapytana, co o tym sądzi, odparła dość zaskakująco: „Niektóre są trochę smutne, ale inne są wesołe. Takie jest życie".

Paradoksalnie utopijna wizja dziecka, dla którego, jak wydaje się wydawcy, tworzy książkę, i rodzicowi - książkę wybiera, czyli dziecka mądrego, dobrze wychowanego, z dużą wyobraźnią, radosnego itd. odbiega od wizji rzeczywistej (której sobie często nie uświadamiają). To realne dziecko-odbiorca, dla którego się tworzy, wyobrażone na podstawie założeń i wymogów jest małe (mniejsze niż na to wskazuje wiek metrykalny) i niewinne, o dużej wyobraźni i małym rozumku. Lektura ma je bawić i prowadzić w baśniowe (a raczej bajkowe) światy, ale nie powinna od niego zbyt wiele wymagać.

Można przywołać tu znaną teorię komunikacji - a zarówno przekład ${ }^{36}$, jak i relacje związane z tworzeniem i wyborem książki są bez wątpienia procesem komunikacji - Erica Berne'a, który wyróżnia w osobowości każdego człowieka trzy stany „ja”: Rodzica, Dorosłego i Dziecka, i przypisuje im charakterystyczne zachowania i reakcje, kolejno: związane z nakazami i zakazami (Rodzic), racjonalną obserwacją i weryfikacją (Dorosły) oraz emocjami (Dziecko) ${ }^{37}$. W procesie między tekstem oryginalnym a dostarczonym młodemu odbiorcy przekładem biorący w tym udział dorośli nie przyjmują czystej pozycji Dorosłego, ale zawsze mieszankę (w różnym stopniu) Rodzica

Zob. J. Levý Przekład jako proces podejmowania decyzji, s. 291. 
i Dziecka. Kontakt z książką dla dzieci ${ }^{38}$ budzi w nich Dziecko, dziecięce marzenia, sentymenty, emocje, z drugiej zaś Rodzica (niezależnie od rzeczywistego posiadania dziecka), a co za tym idzie poczucie odpowiedzialności, prowadzące w skrajnym przypadku do moralizowania i dydaktyzmu ${ }^{39}$.

Wydaje się, że Rodzice, chcąc chronić dziecko, przede wszystkim chcą ochronić samych siebie przed zarzutem niedopatrzenia i stworzyć w świecie literatury utopijny świat: poprawny, bezpieczny, radosny, taki jakie ich zdaniem powinno być dzieciństwo. Co ciekawe, tak ściśle nie cenzurują jednak filmów czy bajek animowanych. Literatura wydaje się podlegać ostrzejszym kryteriom oceny, być może zagrożenie z jej strony wydaje się większe niż ze strony opowieści poznawanych drogą wizji. Opowieści oglądane mogą żyć swoim życiem, książki mają obowiązek być grzeczne, wesołe, poprawne językowo, bezproblemowe - mają być takie, jakimi rodzice chcą widzieć swoje dzieci. Tendencja do wychowywania dzieci przerzuca się na „wychowywanie" książek, co można zrobić tylko w sytuacji przekładu; nikomu nie przychodzi do głowy wymuszanie zmian na autorze (lub zdarza się to bardzo rzadko), jednak w sytuacji przekładu zawsze prędzej czy później pada argument jakiegoś dostosowania tekstu do małego czytelnika.

\section{Tłumacz jako muzyk i jako krawiec}

W praktyce wydawniczej i odbiorze czytelniczym tekst przekładu dla dzieci i młodzieży nie jest ceniony, nie jest traktowany jako pewna wartość, jest jedynie środkiem, dzięki któremu chce się osiągnąć pewne cele, najczęściej dydaktyczne (rozumiane jako umoralniające) i rozrywkowe. Wartościowy przekład literacki w przypadku literatury dla dzieci i młodzieży jest postrzegany zupełnie inaczej niż dla dorosłego czytelnika, a o jego wartości w mniejszym stopniu decydują czynniki tekstowe i merytoryczne (poprawność

38 W przypadku książek dla młodzieży nie jest to takie wyraźne, być może dlatego, że wiek nastoletni nie jest postrzegany jako "sielski, anielski”.

39 Przytoczę tu dwa skrajne komentarze rodziców do Pan Brumm obchodzi Boże Narodzenie. Jedna z mam napisała: „Bajeczka jest bardzo króciutka, ale naprawdę fajna. Ciekawa, zabawna i zaskakująca. Nie tylko dziecku się spodoba, bo ja także świetnie się przy niej bawiłam". Druga zaś: „[...] moim zdaniem nie nadaje się do czytania mniejszym dzieciom. Nielegalna wycinka drewna, włamanie, kradzież i próba oszustwa, hmm to niekoniecznie taki obraz funkcjonowania w społeczeństwie chciałabym przekazywać dzieciom". Zob. http://lubimyczytac.pl/ksiazka/120451/pan-brumm-obchodzi-boze-narodzenie (2.04.2014). 
przekładu, sprawność poradzenia sobie z trudnymi kwestiami, estetyka itd.) ${ }^{40}$, a w większym pozatekstowe, etyczne i emocjonalne. Literatura obcojęzyczna dla młodego czytelnika postrzegana jest nie jako gotowy utwór, ale rodzaj partytury - sugestii wykonania, którą można i należy zmodyfikować dla naszego, z pewnością innego niż obce dziecko odbiorcy. To nasze jest zawsze lepsze i w naszym wyobrażeniu młodsze. Tłumacz nie ma więc wykonać pracy „pod względem fachowym, merytorycznym i językowym na poziomie wymaganym...", ale zaopiekować się dzieckiem, dla którego tworzy, ułagodzić, owinąć, utulić, oswoić, dopieścić i pouczyć. Na tym zdaje się polegać rzeczywiste rozumienie prawniczego terminu "na poziomie, jakiego można wymagać od twórców zajmujących się zawodowo tworzeniem dzieł tego rodzaju" w odniesieniu do przekładu literatury dla dzieci i młodzieży. Tłumacz jest postrzegany jak krawiec, który przykroi i przerobi tekst jak za duże ubranie na użytek naszego dziecka, tak by podobało się w nim dorosłym, a zwłaszcza ukrytym w nim Berne'owskim „Dzieciom” i „Rodzicom” określającym oczekiwania w stosunku do „dobrego" i „wartościowego" przekładu.

Wystąpienie opisanych zjawisk w określonych utworach i sposób ich potraktowania przez określonych tłumaczy oraz podjęte przez nich świadome lub nieświadome wybory powinny być oceniane indywidualnie w konkretnych przypadkach i pozostawać w sferze krytyki przekładu. Ich ocena może być też odmienna z perspektywy różnych osób (tu też często decydują względy merytoryczne i pozamerytoryczne) oraz różnych czasów, gdyż sposób podejścia do kwestii przekładu, w tym przeznaczonego dla młodego czytelnika, rzadko jest ponadczasowy, ale zmienia się w zależności od epoki, współtworząc jej cechy charakterystyczne. Moim celem było jedynie zebranie i opisanie pewnych mechanizmów wewnętrznych i zewnętrznych występujących w wielu przekładach książki dla dzieci i młodzieży oraz uświadomienie ich zarówno osobom decyzyjnym w procesie powstania i publikacji przekładu, jak i czytelnikom biorącym do ręki produkt końcowy, gotową książkę.

40 Wyjątkiem są tu książki postrzegane jako utwory dla dzieci i dorosłych, np. Mały Książę czy Alicja w Krainie Czarów, lub wydania utworów dla dorosłego odbiorcy, np. dla celów naukowych. 


\section{Abstract}

\section{Elżbieta Zarych}

JAGIELLONIAN UNIVERSITY (CRACOW)

Translating Children's and Young Adults Literature: Between the Text and the Expectations of Publishers and Readers

Children's and young adults' literature in translation must be understood from both the textual and the extra-textual perspective. While the 'benefit of the child' is often more important than faithfulness to the original, the different individuals involved in the decision-making process have different ideas of the potential (often utopian) reader and his or her needs. Our expectations of the translation and the translator often simply reflect our expectations of an ideal book - one that the translator, as the author of a version in a given language, is supposed to create on the basis of the 'score' of the original. To understand and to be conscious of the phenomena that occur in this type of translation and the mechanisms that are at work in them is crucial for both publishers and translators, as well as for the readers who reach for the final product.

\section{Keywords}

translation, children's and young adults' literature, publishers, reception 